Article title:

\title{
Beautiful penitent whore: the desecrated celebrity of Mary Magdalene
}

Lucy Bolton, Queen Mary University of London, 1.c.bolton@qmul.ac.uk

\section{Biography}

Lucy Bolton is Senior Lecturer in Film Studies at Queen Mary University of London. She is the author of Contemporary Cinema and the Philosophy of Iris Murdoch (Edinburgh University Press, 2019) and Film and Female Consciousness: Irigaray, Cinema and Thinking Women (Palgrave 2011), and the co-editor of Lasting Screen Stars: Images that Fade and Personas that Endure (Palgrave 2015). She co-edits the book series Visionaries (EUP) and is on the editorial boards of the journals Film-Philosophy, Open Screens and Celebrity Studies.

\begin{abstract}
:
Mary Magdalene is a superstar: a character of perennial cultural fascination in the East and the West, embodying the classic dichotomy of virgin and whore. In this article, I examine her as a celebrity and a film star, using the way in which star studies examines the sources of meaning in a star image, and celebrity studies understands cultural impact and the circle of affect, in order to encompass and analyse Mary Magdalene's complex and contradictory elements. This is an interdisciplinary encounter with Mary Magdalene, from the perspectives of theology, church and art history, feminist film and media studies, celebrity and popular culture. My aim is to provide a means for productive analysis of her unique complexity, when her meaning is obscured and distorted by ideological and cultural red herrings.
\end{abstract}

5 Keywords: 'Mary Magdalene' celebrity stardom theology feminism 
In 1993, Mary Magdalene scholar, Susan Haskins, concluded her book Mary Magdalene, Myth and Metaphor, with this observation:

'If there is still a need for symbolism, would not the true Mary Magdalene, the disciple by the cross and herald of the New Life, no less beautiful than her mythical persona, and far more edifying as a figure of independence, courage, action, faith and love, serve women better as a symbol for today?' (Haskins 1993, p. 400)

The 2018 film, Mary Magdalene, directed by Garth Davis and starring Rooney Mara as Mary and Joaquin Phoenix as Christ, certainly begins the process of revealing Mary Magdalene as such a figure. As New Testament historian Maurice Casey writes, Mary Magdalene has been the historical woman follower of Jesus who has suffered most from 'posthumous fiction', as she has been misidentified, turned into a prostitute, a sinful woman, a concubine, and the mother of Jesus' child (Casey 2010, p. 196). Casey writes, 'none of this is true to the memory of a remarkable woman, who was genuinely devoted to Jesus, and an important figure during his historic ministry in Galilee' (ibid.). Mara's portrayal of Mary in the Davis film does something radical in comparison to the history of Magdalenes onscreen, and indeed in popular culture. Mara as Mary is an observer of Christ; she becomes his spiritual ally and practical helper, as well as a fully active member of his team of followers and a leader of those who go after him to spread his teachings. She has a deeper understanding of Christ's message than the other disciples, and indeed a special loving relationship with Jesus, of which the others are suspicious and jealous. 
The radical element of this depiction is that the relationship is spiritual, not romantic. This is markedly different from Mary's conventional image in popular culture and the depictions of the relationship in the visual arts, and there are some complex and surprising reasons why this is the case. What follows is an interdisciplinary encounter with Mary Magdalene, from the perspectives of feminist theology, church and art history, feminist film and media studies, celebrity and popular culture. Mary Magdalene is a character of perennial cultural fascination, as the epitome of the classic dichotomy of virgin and whore in Western JudeoChristian culture. She has been played by pop stars Yvonne Elliman, Agnetha Fältskog and Melanie Chisholm in various stage and screen productions of the rock-opera Jesus Christ Superstar. ${ }^{\text {i }}$ She fulfils an integral role in the Jesus biopics, and has been played by many star performers including Anne Bancroft, Barbara Hershey, Debra Messing, Juliette Binoche, Monica Bellucci, and now Rooney Mara. A full survey of all cinematic incarnations of the Magdalene is beyond the scope of this article, but I propose that approaching her as a celebrity and a film star, using the ways in which star studies examines the multiple sources of meaning in a star image, and celebrity studies accounts for the cultural impact and affectiveness of an individual, sheds valuable light on her complex image. My aim is to provide a means for productive analysis of her as a unique female figure in popular culture and cultural memory, whose meaning is sometimes obscured by theological or ideological red herrings. As Tammie Kennedy writes,

'Magdalene as an historical and biblical figure has captured the imagination of people throughout history, from New Testament Gospels and Gnostic sources to Christian storytellers, medieval legends, and popular culture. However, such keen interest also exposes women like Magdalene to the politics of public memory. For that reason, it is 
imperative to interrogate the various contexts that inform how she is remembered, by whom, for what purpose, and with what effect' (Kennedy 2012, p. 122).

Mary Magdalene has been the subject of feminist scholarship, but, as Lucy Winkett observes, 'this scholarship has not trickled down through most mainstream memorialisations of Magdalene' (2002, p. 126). The ways in which various discourses and texts circulate around her can be understood as operating along the lines that Richard Dyer describes when he analyses film stardom. Dyer's idea of the circulation and cross-fertilisation of films, publicity, promotion and criticism over time, enables a picture of the journey of Mary Magdalene's image to emerge, as she is transformed from influential follower of Jesus into the figure of the prostitute, wife, and mother of his children. The association of Mary with sex has a lengthy history. As Marina Warner writes,

'The Magdalene, like Eve, was brought into existence by the powerful undertow of misogyny in Christianity, which associates women with the dangers and degradations of the flesh. (Warner 1976, p. 225)

The concept of this dangerously sexual but utterly penitent woman, has been hugely influential and put to institutional, as well as theological, use. As Lucy Winkett observes,

'Mary Magdalene has given her name to homes for fallen women, to the Magdalen laundries popular as workhouses for, among others, women pregnant with the children of priests (with all the attendant imagery of sin and stain). She has given her name to a charity which currently exists to assist women who have had or who are 
having relationships with priests who have committed themselves to celibacy.'

(Winkett 2002, p. 20).

The fact is, however, that there is 'no clear Biblical evidence for this character, Mary Magdalene the penitent sinner' (Winkett 2002, p. 20, original emphasis). Mary Magdalene's reputation was founded on an erroneous conflation of New Testament women, which created a hyperbolic woman embodying lust, adultery and penitence, in a uniquely privileged relationship to Jesus. There are, as Marina Warner said, 'a muddle of Marys' (1976, p. 344), creating what Diane Apostolos-Cappadona calls 'a Magdalen mosaic' (2009, p. 83). ${ }^{\text {ii }}$

\section{Unravelling the 'muddle of Marys'}

The descriptions of each Mary are sparse, and there is overlap between different gospels. There is Mary of Magdala, who is possibly named after her hometown, and who is said to have 'provided' for Jesus. (This is now understood to mean probably financially as Mary Magdalene was relatively well off: Casey 2010, pp. 194, 307.) There is the sinful woman with the alabaster vase, who anoints Jesus' feet with expensive ointment, or nard, and wipes his feet with her hair; the woman who has seven demons cast out of her, taken by the later church to be demons associated with sexuality; there is Mary of Bethany; Mary, sister of Martha and Lazarus; Mary the mother of James and Joseph; and most commonly across the gospels, and by far most significantly, there is Mary Magdalene who refused to leave Jesus on the cross, stayed with him until he died, and was the first person he appeared to on the third day when he rose from the dead. She mistook him for a gardener, suggesting that perhaps his appearance had changed, and Jesus called her by her name, 'Mary', saying 'do not touch me for I have not yet ascended to my Father; but go to my brethren and say to 
them, I am ascending to my Father and your Father, to my God and your God' (John 20, v17). This exchange has inspired many paintings and depictions of this moment, known as the 'Noli me tangere' ('touch me not', Ferguson 1961, p. 90, 134; Drury 2002, pp. 21, 116120). Mary Magdalene is mentioned at least twelve times in the gospels, which is more than most of the apostles. In Apostolos-Cappadona's words, 'early ecclesiastical authors' (2002, p. 8) created cross identifications and confusions. Formative texts of church fathers were unsure what to do with Mary, but Pope Gregory the Great 'concluded that a multiform Magdalene who was both sinful and penitent would prove more salutary to Christendom' (ibid, p. 15). He took the unction scenes (with the ointment), conflated the casting out of the seven demons with immorality and sinfulness, and, in 591, proclaimed that Mary Magdalene was all of these women (Apostolos-Cappadona 2002, p. 15; Winkett 2002, p. 21).

Thereafter, the western Christian tradition worked with this multiform Mary: 'one woman who was a sinner, penitent, anointer, and follower as well as witness to the Resurrection' (ibid). As Winkett summarises, 'The false equation Mary of Magdala = woman with ointment $=$ woman at the well $=$ 'loose woman' $=$ prostitute has produced the composite figure of Mary Magdalene' (2002, p. 21). This distortion continued across the centuries in the Western Christian tradition, although it was not followed in the Eastern Orthodox churches (ibid.). It wasn't until 1969 that the Roman Catholic Church formally revised the canonical definition of Mary Magdalene, conceding that there was no evidence in the Bible that she had been a prostitute (Haskins 1993, p. 25). It was now accepted that she was not the unnamed adulterer or Mary of Bethany (Ibid, p. 26). The Eastern Orthodox Christian tradition had kept alive the idea that, as first witness to the resurrection, Mary was the apostle to the apostles as the bearer of the news of the Resurrection (Winkett 2002, p. 23). In 2016, Pope Francis took what Alon Berstein and Isaac Scharf call 'the biggest step yet to rehabilitate Mary 
Magdalene's image by declaring a major feast day in her honour on 22 June' $(2018, n p){ }^{\text {iii }}$ This decree, they argue, 'put the woman who first proclaimed Jesus' resurrection on par with the liturgical celebrations of the male apostles' (ibid.) and redresses the inaccuracy for which the church has been responsible since the $6^{\text {th }}$ century.

\section{Meeting Mary on stage and screen}

This perspective of theological history sheds light on the process of the desecration of Mary's image, but there can be little doubt that she remains a relevant figure in Western culture, as the Davis film confirms not only by its existence but also by the significant media coverage that it attracted (Bamigboye 2018; Bradshaw 2018; Carr 2018; Warren and Edwards 2018). A production of Jesus Christ Superstar ran at the Regent's Park Open Air Theatre in London in 2016 and 2017, transferring to the Lyric Opera of Chicago in 2018 and London's Barbican Centre in 2019. Representations in art, theatre and films are the most common way the world experiences Mary, not the verses in the Gospels or the processes of Biblical interpretation. In this way, Mary Magdalene can be considered as a culturally fabricated celebrity, along the lines described by Chris Rojek, who considers celebrity as 'the attribution of glamorous or notorious status to an individual within the public sphere' (2001, p.10). Glamour is favourable, notoriety unfavourable (ibid.), and Mary Magdalene has had both of these facets attributed to her. To understand how her celebrity has played out in art, cinema and popular culture, I will analyse some incarnations of Mary Magdalene and explore the themes and tropes that pervade her star image, visually and conceptually.

The first thing to note is that there have been more than forty onscreen Mary Magdalenes, from 1912 to 2018. She is a hybrid of a recurrent starring role and a historical character: like 
a cross between Hermione from the Harry Potter films, playing second fiddle to the central 'special' male character, and Marie Antoinette, a historical woman who attracts controversy and glamorisation. This is how the discourse of stardom pertains to Mary Magdalene; as Richard Dyer proposed, 'star images are always extensive, multimedia, intertextual' (2003, p. 3). These images also 'have histories, and histories outlive the star's own lifetime' (ibid.). Despite the fact that these contemporary texts refer to a woman who lived in the first century of the common era, the ways in which her lifestyle, persona, work and personal life have remained in social currency reflect upon the independence of the star persona from the person, and the circulation of the elements of celebrity, long after the person has died.

Richard Ascough writes how there are periods in the development of Jesus as a film character: the passive Jesus, the absent Jesus, the Epic Jesus, and others (2009, pp. 179-183). Ascough invites us to analyse these from various perspectives: narrative and artistic, historical and intertextual, cultural, ideological, theological (ibid, pp. 183-186). These different Jesuses, and various ways of understanding them, are useful for comparing to the incarnations of Mary Magdalene onscreen, which appear to be so similar to each other. Adele Reinhartz argues, however, that there has been change. She says,

'Until the 1980s, Jesus biopics played up Mary’s promiscuous past; the later films ... do not necessarily ignore this traditional view of Mary as a repentant whore but neither do they emphasize it nor do they pass moral judgement upon her to the same extent as do the earlier films'. (2007, p. 148)

Reinhartz concedes, however, that 'By far the most persistent element in Mary Magdalene's public image is sexual promiscuity' (2007, p. 127). Consistencies across the films shape her 
image as a star, not least the fact that she has been played by so many star performers. Edgar Morin, in 1957, talked about stars as celestial beings; he called Garbo, for example, 'a survivor of the twilight of the Gods' $\left(1957\right.$, p. 16). ${ }^{\text {iv }}$ Richard Dyer's semiotic approach penetrated this mysticism, dividing the texts that go towards making up a star image into four categories: the films, featuring the appearances of the star onscreen; the critical work done on those films and roles, and the analysis of performance, costume, direction, character; publicity, which was often unintentional notoriety or off-screen news that associated with the star; and promotion, which the studios themselves put out in order to promote a particular film, and a particular star (1979, p. 60). The complex star image holds various elements in tension, resolving contradictions by embodying them in one image of one person (Dyer 1979, p. 64). This framework helps us to understand how Mary Magdalene works as a movie star and a celebrity. There is a split between the private self and the onscreen self (Rojek, 2001, p. 11), as cinematic descriptions create a character that has its own qualities. This is a character full of contradictions: both sexual sinner and companion of Jesus, both prostitute and repentant apostle, carer and cared-for, all embodied in the one woman, the 'multiform Mary' of Pope Gregory. Thinking about Dyer's analytical categories in relation to Mary, there are the films, which feature an array of beautiful, penitent whores; promotion, which we can consider to be the gospel verses, including the Gospel of Mary; publicity, which is the Christian church's work to turn her from 'apostle to the apostles' into repentant sinner; and the criticism, feminist theology and church history mainly, which have worked to bring her her back 'from penitent prostitute to a prominent disciple of Jesus' (Beavis 2012, p. 145). I will consider these categories one by one, before demonstrating their circularity, and the links to the celebrity 'circuit of affect' (Redmond 2019, p. 14) which the Davis film reinvents so powerfully. 


\section{Mary Magdalene according to Dyer}

The films featuring Mary Magdalene range from the days of early cinema with Sidney Olcott in 1912, and Cecil B. DeMille's King of Kings in 1927, to Hollywood blockbusters in the age of Technicolor, such as Nicholas Ray's King of Kings (1961) and George Stevens' The Greatest Story Ever Told (1965); versions by European directors such as Franco Zeffirelli's Jesus of Nazareth in 1977, the Jesus Christ Superstar musical onscreen (Jewison 1973), and re-imaginings of the story by American auteurs such as Martin Scorsese, Abel Ferrara and Mel Gibson.

The Jesus Biopic is a popular genre with a reliably gripping narrative, and, as Joey Eschrich writes, despite different characterisations, the construction of Jesus's masculinity (from 1961 -2004) remains 'relatively consistent and unresponsive to social and cultural changes' (Eschrich 2011, p. 523):

'The films continually recognize various crises of masculinity and continually propose the same limited model of masculinity, defined against femininity, homosexuality, and hypermasculinity, as a means to ameliorate the crisis.' (ibid, p. 524)

Judas and John the Baptist as examples of hyper-masculinity, Herod as effete homosexuality, and Mary Magdalene as sexuality and femininity, are figures that enable Jesus to demonstrate the type of man he is. As Eschrich notes, in relation to Mary's sexuality, 'Jesus overcomes this temptation and subjugates it to a chaste male authority that controls sexual expression; 
his ability to resist and control sexuality marks him as masculine' (Ibid, p. 525). Mary Magdalene functions, usually, to affirm Jesus' asexuality and kindness towards women: the portrayal of her is as the whore, the adulteress who Jesus saves from stoning, and the penitent sinner, transformed through repentance into a nun-like character. As a character, Mary borrows elements from the personas of the stars who portray her in a circulation of meanings about femininity and womanliness (Bolton 2015): actresses renowned for their sexuality, treated by Hollywood as generically 'off-white' due to their ethnicity (Negra 2001), and considered to be ageing, in that they are usually in their thirties or forties. Ian Jarvie describes how stars in Hollywood with ethnic identities have traditionally played many types of ethnicity different to their own (2003, p. 168), evident in the casting of the stars who have played Mary. Vicente Sanchez-Biosca explains how the reasons for this are 'in cultural dialectics between the "WASP" and the "Other", and briefly considers Carmen Sevilla, the Spanish actress who played Mary Magdalene in King of Kings (2001, p. 136). Because of the 'otherness' that filmmakers seek to portray as integral to Mary, actresses who are 'off-white', or with ethnic 'otherness' in Hollywood are cast, including the Italian Bellucci, French Binoche, Jewish Hershey and Italian-American Bancroft. The combination of femininity and ethnicity is thereby mobilised, evidencing Negra's description of how 'the ethnic female star is a figure of great potential ideological disruption, for she threatens to expose the fragile construction of white, American patriarchy' (2001, p. 8).

In The Passion of the Christ, Monica Bellucci as Mary Magdalene has a flashback of Jesus saving her from being stoned when she is wiping up his blood after his scourging. This Mary weeps at the foot of the cross, but is not shown when Jesus rises from the dead. In most films Mary is present at the crucifixion, but the risen Christ revealing himself to her is shown inconsistently. Some mention the casting out of the demons, including the animated film The 
Miracle Maker (Hayes and Sokolov 2000), which shows Mary Magdalene as an outsider in her village. She runs around like a schoolgirl, shouting 'I have seen the Lord - he's alive!' She imparts the news hysterically, and is met with cries of 'The grief has made you mad'. In Jesus of Montreal (Arcand 1989), a theatre troupe puts on a Passion play but also characters match up with those of Jesus and Mary in the film's narrative. The film shows a kind of agape, or love for all, and is an unconventional take on these characters and their stories.

There are a variety of emphases across the films, then, but two of the most influential portrayals have been those from Scorsese's The Last Temptation of Christ, and Franco Zefferelli's Jesus of Nazareth. In the Scorsese film, we see Jesus, played by Willem Defoe, watching Mary Magdalene having sex with her clients, and then speaking to her about the forgivenness he needs from her before he goes off into the desert. This sequence is troubling for many reasons, not least because Hershey was dedicated to this hyper-sexualised and degraded characterisation. The role was co-authored by Barbara Hershey and Scorsese, and, in Tammie Kennedy's words, this characterization 'imprisons her in popular culture's collective consciousness as a reformed prostitute with no apostolic authority, a woman whose agency is usurped by patriarchal discourses' (2005, p. 4). Hershey used Henna tattoos on her face, hands and body as part of her back story, explaining that Magdalene is trying to 'make herself despicable because she's trying to be the lowest of the low' (ibid, p. 14). She rejected use of body double, saying 'I knew if I did the scene, I'd really feel like a whore' (ibid, p. 17).

\section{INSERT FIGURE 1 NEAR HERE}

Figure 1. Mary Magdalene (Barbara Hershey) lies stoned and demeaned on the ground, in The Last Temptation of Christ (Scorsese, 1988) (Author's screenshot). 
Hershey clearly wanted to play the role provocatively, but her characterisation perpetuated in fact heightened - the image of Mary Magdalene as a sexually threatening woman, humiliated and punished by patriarchy, who is completely redeemed by accepting the word of Jesus (King 2011, p. 83). Indeed, the controversy of the film was based on the involvement of Jesus in her sexuality: by watching her having sex and by featuring in a fantasy of them making love, marrying, and having children together (Kennedy 2005, paragraph 7).

Anne Bancroft is a mature and interesting Mary Magdalene in Franco Zefferelli's Jesus of Nazareth (1977). She is not shown as the adulteress (in this version that role goes to Claudia Cardinale), rather she is introduced as a working prostitute, being persecuted by the boys in the village, and told that 'the curse of God is upon her'. A client tells her about Jesus, who eats and sits with the sinners. Mary watches Jesus perform the miracle of the loaves and the fishes; she is shown studying Jesus and the crowds, and is moved by what she sees. We next see her when she humbles herself by crawling on the floor, washing and kissing Jesus' feet. The Pharisee says 'do you know what kind of woman this is?', but Jesus declares her gesture as an act of love and says she is forgiven, and that she should go and sin no more. He says, 'your faith has saved you'. This transforms Mary who becomes a sombre follower, now looking like a nun in her costume.

\section{INSERT FIGURE 2 NEAR HERE}

Figure 2. Mary Magdalene (Anne Bancroft) turns her back on her profession and becomes a follower of Jesus, in Jesus of Nazareth (Zeffirelli, 1977) (Author's screenshot).

She attends the crucifixion, stands at the cross, kisses the dead Jesus' foot, and goes to the tomb on the third day, to anoint the body. She sees two gardeners, who speak to her and ask her why she looks for the living amongst the dead, but no conversation with Jesus is shown. 
She then goes to the other apostles, who are in hiding, and tells them that she has seen Jesus resurrected. They dismiss her as being tired and grief-stricken: 'Women's talk', they mutter. She lacks the authority in the film of being shown to have been given specific instruction from Jesus, which is portrayed in some films and of course in the gospels. But this scenario extends Mary's story beyond the scenes with Jesus, showing her strength and her willingness to argue. She states, 'I saw him die, I stayed with him until the end, why then should he not then appear to me?' With this, Mary stakes a claim in the story of events after the resurrection. The scene also shows her as apostle to the apostles: a significant element of the gospels which is not shown consistently across the films in which she features.

Another significant feature of Mary Magdalene's image is her physical appearance. Notable across the films is her beauty and sensuality, conveyed by long flowing hair, hair ornaments, jewellery, nudity or loose clothing, and make up (strong dark eyeliner, red lips). This tends to make her look more like a European sex goddess than a saint, as noted by Michael Grimshaw, commenting on Nicholas Ray's The Greatest Story Ever Told, featuring Max von Sydow as Jesus and Joanna Dunham as Mary:

'This is Jesus as the pallid evangelical, who not only again spends all his time with other young men, but also manages to desexualize and domesticate the fiery Bardotclone fire-cat Magdalene' (Grimshaw 1999, p. 152).

\section{INSERT FIGURE 3}

Figure 3. Mary Magdalene (Joanna Dunham ) resembles a European sex goddess in The Greatest Story Ever Told (Stevens, 1965) (Author's screenshot). 
These sexualised images have been based on depictions in Christian teaching, or, as we might deem it in Dyer's star studies terminology, Mary Magdalene's publicity. The work done by the church over the years created a character who is sexually sinful and a successful repentant sinner (Winkett 2002, p. 23). The degradations of sinful sexuality have dominated her image since: and indeed, images of women in Western Culture. As Marina Warner writes,

'Together, the Virgin and the Magdalene form a diptych of Christian patriarchy's idea of women. There is no place in the conceptual architecture of Christian society for a single woman who is neither a virgin nor a whore.' (1976, p. 235).

We might then consider the history of Christian art to also be further publicity for Mary Magdalene. As Diana Apostolos-Cappadona has set out,

'The symbolism of Christian art was premised upon the visual literacy of those who looked at the images, motifs, and symbols. Thereby, to understand the meaning of an event or a person such as Mary Magdalene, we must look at the history of her iconography and incorporate what we learn from looking into the frame of scriptural tradition' (2002, p. 8, emphasis in original).

This stressed the importance of the visual image, and the significance of what Mary looks like. Lucy Winkett describes how, in most paintings of the character Mary Magdalene, 'she is depicted lying down, kneeling at Jesus' feet, clinging to him in the garden, listening in Bethany, weeping at the cross' (2002, p. 22). Mary Magdalene is 'often naked - or at least her breasts are uncovered - and there is a jar of ointment, a skull and crucifix, illustrating her immersion in the suffering of Christ and her own humiliation and shame'. (ibid.) 
The influence of art on film is particularly seen in the depiction of the punishing of the adulteress, when Jesus says to the crowd, 'let him who is without sin among you be the first to throw a stone at her' (John 8, v 7: no mention of Mary here). The woman lying at his feet, hiding behind him, terrified, and saved, is an attractive and filmic image, such as that by Gustave Doré in 'Woman Taken in Adultery' (1832-1833; Apostolos-Cappadona 2002, p. 41). We see Hershey, Dunham and Bellucci in this terrified, humbled posture (Figures 1, 3 and 4).

\section{INSERT FIGURE 4 HERE}

Figure 4. Demeaned and desperate, Mary Magdalene (Monica Bellucci) is rescued by Jesus, in The Passion of the Christ (Gibson, 2004) (Author's screenshot).

It is not just costumes, hair or nudity, then, where the influence of art is seen in film, it is in postures and gestures as well; such an integral part of an actor's performance. But it is not a simple transposition of images from art to film. As Apostolos-Cappadona argues, to understand 'the role of iconography in film, several central issues arise here - how an image functions; how images garner meaning; and the history, if any, of this "power of images"” (2009, p. 442). What art can do is provide a visual vocabulary of postures, gestures, facial expressions, and dress, that is missing clearly from the Biblical narrative. ApostolosCappadona talks about the resurrection narrative where Mary encounters the risen Christ, and explains how there are so many 'spaces between' their words and actions. ${ }^{\mathrm{v}}$ She asks, 'What are the visual clues that lead Mary Magdalene to believe that the man before her is a gardener; his costume? The objects in his hands? His actions? ... How does she gesture or posture; what is her facial expression in the moment of this recognition?' (ApostolosCappadona 2009, p. 444). These gaps and possibilities have offered opportunities to the 
visual arts over the centuries to produce an array of gestures and expressions in their place. It is notable that, for example, many paintings equip Jesus with a hoe or gardening implement to explain Mary's misidentification as a gardener (Drury 2002, pp. 116-119).

\section{The Resurgence of Mary Magdalene}

In the film based on Dan Brown's novel of the same name, The Da Vinci Code (Ron Howard, 2006), Sir Leigh Teabing (Ian McKellen) 'solves the riddle' of the Holy Grail for Robert Langdon (Tom Hanks) and Sophie Neveu (Audrey Tatou): the Grail was not a chalice, it was Mary Magdalene, carrying Christ's child. ${ }^{\text {vi }}$ Sophie says in response to the mention of Mary, 'the prostitute?', to which Teabing exclaims 'She was no such thing! Smeared by the church in 591 AD poor dear. The Magdalene was Jesus's life! A woman who carried a secret so powerful that if revealed it could devastate the very foundations of Christianity'. Teabing uses the image of Leonardo de Vinci's Last Supper on his computer screen to make his case, cutting and pasting the image to highlight a feminine figure. As Apostolos-Cappadona puts it, 'we no longer ask ourselves in unison with Langdon and Sophie Neveu - "is there a woman in that painting?" - rather we question why we never saw her there before!' (Apostolos-Cappadona 2009, p. 461). This scene highlights the layered use of iconography in film, as it draws on the imputed legitimacy of historical religious art in visual support of its assertion.

Relatively recent literary and cinematic texts that reconsider the importance of Mary Magdalene can be viewed as Dyer's category of promotion, alongside what is written about Mary Magdalene in the New Testament and the Gnostic gospels: these verses speak of the 
significance of Mary's role in the ministry, crucifixion, resurrection and apostleship of Jesus. The New Testament mentions are discussed above, but in the Gospel of Mary, thought to have been written in the 2 nd century and rejected by the mainstream church, Mary is preferred above all the disciples and said to have a special spiritual understanding of Jesus' message (Leloup 2002, p. 31). The texts (now only surviving in fragments) describe how Mary's role developed in early Gnosticism, showing how highly women were thought in this tradition of as opposed to that of mainstream churches, but 'has nothing to do with the historical Jesus or the historical Mary Magdalene' (Casey 2010, p. 537). The Gospel of Mary, does, however, offer some different understandings and messages about Mary which have informed feminist scholarship, and which shed light on the contemporary shifts in her image. Analysing and understanding this text, as well as the work of getting behind the desecration of Mary Magdalene, has been mainly carried out by feminist theologians, which leads me to the last of Dyer's sections, on criticism and commentary. Leading work by Joan Taylor is investigating the question of what Mary Magdalene really looked like, as a historical woman living in first century Judaea. ${ }^{\text {vii }}$ Judaeans, Taylor explains, would have been of 'Middle Eastern' appearance, with 'a strong biological connection with people from the area of contemporary Iraq' (Taylor 2017). There is no information about Mary Magdalene's age. Her name indicates independence because it is free of any association with a man but rather refers either to where she was from, Magdala, or, Taylor suggests, to the word for 'tower' in Aramaic, 'Magdal' (Winkett 2002, p. 24). Taylor also points out that 'there is absolutely nothing in our texts that would require us to imagine Mary as young, or as beautiful' (Taylor 2017).

This is the type of critical work that is going on now amongst Mary Magdalene scholars, as well as scholarship which is reviewing the work of the women apostles more broadly. ${ }^{\text {vii }}$ 
Film criticism has omitted to tackle the inaccuracy of representation of Mary Magdalene, probably because these characterisations serve to fulfil well established pattern. As Molly Haskell set out in 1987, in From Reverence to Rape, the bad girl/good girl, whore/virgin, is a wonderful dichotomy for cinema (Haskell 1987, p. xiii). Anton Karl Kozlovic writes about how there have been 'cinematic Christ figures' in the history of cinema, such as Christopher Reeve's Superman, or Klaatu in The Day the Earth Stood Still, or Neo in The Matrix (Kozlovic 2004). There are many Mary Magdalene characters too, who embody both the virgin and the whore, and frequently make the move from one to the other. Always involving physical beauty and sexuality, usually shoring up stereotypes of the cool blonde and hot brunette, perhaps they are an enigmatic femme fatale, perhaps they are flagrant (Campbell, 2006); often there is a chance for there to be two stars playing the roles, such as Eva Marie Saint and Elizabeth Taylor (The Sandpiper and Raintree Country); or Kim Novak and Kim Novak as Madeleine and Judy, in Vertigo, often voted the best film ever made. ${ }^{\text {ix }}$

Most of the films featuring the character Mary Magdalene have generally been Jesus biopics, with Mary in a supporting role, consolidating and reflecting the Jesus story. There is, however, a growing body of films about Mary Magdalene herself, including a television film starring Maria Grazia Cucinotta, Mary Magdalene (Raffaelle Mertes, Elisabetta Marchetti, 2000), which interestingly ends with Mary healing a blind man; and Abel Ferrara's film Mary (2005), with Juliette Binoche as an actress playing Mary in a role and wanting to find out more about her. There have been several documentaries over the past few years which promote conspiracy theories with dramatic soundtracks and sensationalist content (Fothergill 2009; Januzczak 2017). Most of these have been keen to capitalise on The Da Vinci Code. Eric Plumer writes about the appeal of Dan Brown as being based on 'The satisfaction people feel at seeing Mary Magdalene recognized for her importance in Jesus' life and cleared of the 
charge of being a prostitute' $(2009$, p. 241). Plumer says: 'It has taken fourteen centuries for the tide of presumption against Mary Magdalene to turn. As Dan Brown said, her time has come' (Plumer 2009, p. 241).

This leads me to the 2018 film, Mary Magdalene. Directed by Garth Davis, starring Rooney Mara, of Carol (Haynes 2015) and A Ghost Story (Lowery 2017), and written by two women, Helen Edmunsen and Philippa Goslett, this is a groundbreaking addition to the genre. The film is very much from Mary's point of view, in visual and narrative terms: she is an unorthodox young woman, with special talents and a strong will not to conform. The film strips away many of the myths of Mary Magdalene, and shows some of the neglected elements, such as preaching, baptising, and conversations with Jesus. It certainly draws on feminist theological scholarship and ideas from the Gospel of Mary, and the writers consulted extensively with theologians and historians (Clarke 2019). In this film, Mary is framed as the only disciple who truly understands Jesus's spiritual message as being about change in the hearts of people on earth, which puts her in direct conflict with the apostle Peter (Chiwetal Ejiofor). The disciples are waiting for Jesus to overthrow the Romans and create a new kingdom, but Mary has come to the conclusion that the kingdom is here and now, within us. The film stays with Mary throughout the time when the more familiar masculine imagery and characters dominate: this film features no Herod, Pontius Pilate, or Barabbas. Mary is knocked unconscious by a guard who comes to arrest Jesus, and although she runs after the crowd to find out what is happening, she passes out again, only coming to when Jesus is carrying his cross to the site of the crucifixion. We have stayed with Mary, as we do when she stands at the foot of the cross, and Christ says to her 'You will be my witness'. This is her story, and it is primarily a spiritual and intellectual one. Mary describes to the hiding apostles the meeting she had with Jesus following his death, and Peter grows hostile, asking why 
Jesus would grant Mary - a woman - with such a vision. Peter accuses Mary of weakening them, and says she also weakened Jesus. Mary will not be bowed, however. She says, 'I will not be silent. I will be heard.'

Liza Knapp points out that official and unofficial Christian sources have suggested that there was a 'rivalry between Mary Magdalene and the male apostles, and this rivalry has been carried on by their spiritual heirs' (Knapp 1999, p. 598). Despite the basis in scholarship, the film was seen by some to be twisting Jesus narrative to fit today's political agenda (Carr 2018). Warren and Edwards criticised the film's 'subtly negative depiction of Jewishness' (2018). They dispute how matters unfold in the synagogue, in relation to the separation of genders; Hebrew is used rather than Aramaic; and the prayers are too modern. They also object to the idea that revolutionary Jesus came along and made everything better, by including women, opposing Judaism of his day. They see this as a matter of faith (embodied by Jesus) versus ritual, and they believe it is overstated. These are theological objections. The same authors also accuse the film of being 'yet another example of Hollywood whitewashing' (Edwards and Warren 2018). They object to the racial make-up of the cast, especially the white Jesus and Mary, and the array of accents, particularly Chiwetel Ejiofor who speaks with an African accent. They ask why Davis did not hire an African actor, and suggest that the film associates Peter's race and ethnicity with misogyny, because Peter is often opposed to Mary (ibid.). This discussion of whiteness and whitewashing is of course central. Director Davis says Mara has an 'otherworldliness' that he wanted to use: saying there is 'no other actress like her' (Allen 2018). Carol (Cate Blanchett) says of Mara as Therese (2015), that she is 'a strange girl... flung out of space', and the description rings true because of Mara's ethereal qualities. I was at a preview of the Davis film where a male journalist said his experience of the film was interrupted because of Rooney Mara's beauty. 
These objections are important, mainly because - as Apostolos-Cappadona observed - Mary Magdalene has been understood and defined by how she looks, and so her image is vital to how people perceive her and relate to her. Rooney is paler and more blue-eyed than previous more ethnically 'other' actors such as Hershey, Bancroft and Bellucci (Figure 5).

\section{INSERT FIGURE 5 HERE}

Figure 5. Rooney Mara is pale and ethereal in Mary Magdalene (Davis, 2018) (Author's screenshot).

There are more racially accurate representations of Mary Magdalene in other more lowprofile productions, and hopefully these will contribute to the changing perceptions of her (AD The Bible Continues 2015; The Bible 2013) It would certainly have been more accurate had Davis cast a star with a more Middle Eastern or Jewish appearance.

The film is physically affective in its evocation of Mary's life and experience. It draws on familiar tropes of expressing femininity, such as haptic engagements with fabrics and water, in order to concoct Mary's sensory world. The link with water and the sea is an element of feminist scholarship on Mary Magdalene, with a basis in the Eastern Orthodox tradition (Knapp 1999, pp. 603-604). The tactility of fabrics in film has been written about extensively, including the groundbreaking work of Laura Marks on haptic visuality (2000, p. 168). Sean Redmond describes how celebrity culture is 'unquestioningly an affective machine' (2019, p. 17). Redmond asks us to close our eyes and imagine our favourite celebrity is standing before us.

'As you do try to experience them as a body, a surface and as sound. Sense your celebrity as enveloping textures and qualities. Smell their perfume or eau de cologne. 
Hear their voices as a synaesthetic register, not just composed of sound but colour, taste and light. (2019, pp. 14-15)

Redmond invites us to 'Experience your celebrity as a cross-modal encounter' (2019, p. 15).

This is an invitation that the Davis film also issues. This film creates a sensory, contemplative and physically affective engagement with Mary Magdalene, which goes a long way to flesh out a fuller characterisation, enabling us to connect with her experiences in the world.

Whether it is being forcibly immersed in water by her male relatives until the point of nearly drowning in an attempt to drive out evil spirits, or realising the menace of a delicately embroidered and folded wedding garment as the match she dreads is being arranged, these tactile and sensory encounters fit how Redmond describes that, 'the circuit of affect is an attempt to give definition and visibility to these lost, emotive tones' $(2019$, p. 15). It is a fuller understanding of Mary Magdalene as a woman, with a history of desecration and misidentification, that enables an appreciation of the Davis film as a space 'for heightened experiential encounters, and for the circulation and transmission of intense affects that are often empowered and empowering' (ibid., p. 16). In this film, the circuit of celebrity culture and the circuit of celebrity affect intersect, shored up by visual style, costume, point of view and performance style, as well as storytelling and characterisation, which offer a not only a challenge to representations that have come before but also new opportunities for the future. As Mara's Mary asserts that she will be heard, Winkett's description of the possibilities for Mary's influence can be seen to have been met:

'What Mary Magdalene teaches us is that it is part of a woman's God given calling to speak publicly about what she believes. Women's spirituality as a whole is not to be defined or confined to the private sphere'. (2002, p. 28) 
The final shots of the film, as women begin to follow Mary and be baptised by her, also respond to Winkett's belief that, from Mary Magdalene's story, 'Christian women can rediscover the notion of solidarity and communion with one another' (2002, p. 30). Mary is shown in this film to engage in midwifery, to baptise and preach to women, and to lead them into the future. She is, as Winkett proposed, 'a woman who stands her ground and lives courageously' (ibid, p. 25). This is a strong feminist theological message, which is a significant departure in terms of Mary Magdalene's star image. (Figure 6)

\section{INSERT FIGURE 6 HERE}

Figure 6. Mary Magdalene (Rooney Mara) is a strong and inspiring leader for women (Davis 2018) (Author's screenshot).

I have given an idea of the types of filmic representations of the celebrity Mary Magdalene, and also some of the reasons why, such reasons having historical, theological, cultural and industrial factors. The Davis film shows her as having a cerebral, spiritual life as well as a practical one, and a brain as well as a body. It is especially successful in changing the conceptual framework for approaching the woman and the name of Mary Magdalene, in that it conveys her central role in the historic ministry (Casey 2010, p. 194). For a figure whose image is so founded on the visual, it is vital that an understanding is achieved about what she would have most likely looked like. A depiction that challenges the race, class, and age of the Mara performance would be welcome. In the meantime, I have argued that approaching the figure of Mary Magdalene, still so prevalent and recurrent in popular culture, through the discourses of celebrity and stardom enables a sufficiently multifaceted approach to account for the interdisciplinary and multivalent complexity of her image. 


\section{References}

AD The Bible Continues, 2015. Television series. USA: United Artists.

Allen, B., 2018. Mary Magdalene director Garth Davis responds to 'whitewashing' claims [online]. Radio Times. Available from: https://www.radiotimes.com/news/film/2018-0316/mary-magdalene-director-garth-davis-responds-to-whitewashing-criticisms/ [Accessed 20 January 2019].

Apostolas-Cappadona, D., 2002. In Search of Mary Magdalene: Images and Traditions. New York: American Bible Society.

Apostolas-Cappadona, D., 2006. Sidebar: Mary Magdalene and the Goddess Image. In: D. Burstein and A. de Keijzer, eds. Secrets of Mary Magdalene. London: Weidenfeld and Nicholson, 83.

Apostolas-Cappadona, D., 2009. Iconography. In: J. Lyden, ed. Routledge Companion to Religion and Film. Oxford: Routledge, 440-64.

Ascough, R., 2009. Jesus: Real to Reel. Word \& World, 29 (2), 179-186.

Bamigboye, B., 2018. Brilliant Rooney brings St Mary to life [online]. The Daily Mail. Available from https://www.dailymail.co.uk/tvshowbiz/article-5342513/Rooney-Maraspassionate-performance-Mary-Magdalene.html [Accessed 20 January 2019].

Beavis, M., 2012. The Deification of Mary Magdalene. Feminist Theology, 21 (2), 145- 154. 
Bernstein, A. and Scharf, I., 2018. Long maligned, Mary Magdalene now seen as stalwart disciple [online]. Times of Israel. Available from: https://www.timesofisrael.com/longmaligned-mary-magdalene-now-seen-as-stalwart-disciple/ [Accessed 21 January 2019] Bolton, L., 2015. The Intertextual Stardom of Iris: Winslet, Dench, Murdoch and Alzheimer's Disease. In: A. Backman Rogers and L. Mulvey, eds. Feminisms: Diversity, Difference and Multiplicity in Contemporary Film Cultures. Amsterdam: Amsterdam University Press, 65-75

Bradshaw, P., 2018. Mary Magdalene Review [online]. The Guardian. Available from: https://www.theguardian.com/film/2018/feb/27/mary-magdalene-review-rooney-marasunday-school-myths [Accessed 20 January 2019].

Brown, D., 2010. The DaVinci Code. London: Corgi.

Campbell, R., 2006. Marked Women: Prostitutes and Prostitution in the Cinema. Madison, Wis: University of Wisconsin Press.

Carr, F., 2018. The real reason why Mary Magdalene is such a controversial figure [online]. Time. Available from: http://time.com/5210705/mary-magdalene-controversial/ [Accessed 21 January 2019].

Casey, M., 2010. Jesus of Nazareth. London and New York: T\&T Clark International.

Common Bible, Revised Standard Version, 1973. London; New York: Collins.

Clarke, S., 2019. Interview with Philippa Goslett. Variety. Available from: https://variety.com/2019/film/news/mary-magdalene-philippa-goslett-neil-gaiman-himalaya1203187903/ [Accessed 1 May 2019].

Cox, A., 2018. Jesus's Female Disciples: the New Evidence. UK: Timeline.

Drury, J. M. (2002) Painting the Word: Christian Pictures and their Meanings. New Haven, Conn. and London: Yale University Press in association with National Gallery Publications. Dyer, R., 1979. Stars. London: British Film Institute. 
Dyer, R., 2003. Heavenly Bodies. London, New York: Routledge.

Edwards, K., and Warren, M.J.C., 2018. Mary Magdalene is yet another example of Hollywood whitewashing [online]. The Conversation. Available from:

http://theconversation.com/mary-magdalene-is-yet-another-example-of-hollywoodwhitewashing-94134 [Accessed 21 January 2019].

Eschrich, J., 2011. Behold the Man! Constructing the masculinity of Jesus of Nazareth in mainstream American film. Men and Masculinities, 14 (5), 520-541.

Ferguson, G., 1961. Signs and Symbols in Christian Art. Oxford: Oxford University Press. Grimshaw, M., 1999. Sexless Piety or a Man's Man? Notes on the Cinematic Representation of Jesus. Journal of Beliefs and Values, 20(2), 149-61.

From the Manger to the Cross; or, Jesus of Nazareth, 1912. Film. Directed by Sidney Olcott. USA: Kalem Company.

Haskell, M., 1987. From Reverence to Rape: The Treatment of Women in the Movies. Chicago: University of Chicago Press.

Haskins, S., 1993. Mary Magdalen: Myth and Metaphor. London: HarperCollins Jarvie, I. C., 2003. Stars and Ethnicity: Hollywood and the United States, 1932-1951. In: L. Fischer and Marcia Landy, eds. Stars, The Film Reader. London: Routledge. 167-180. Jesus Christ Superstar, 1973. Film. Directed by Norman Jewison. USA: Universal Pictures. Jesus of Montreal, 1989. Film. Directed by Denys Arcand. Canada: Max Films Productions. Jesus of Nazareth, 1977. Film. Directed by Franco Zeffirelli. Italy; UK: ITC Films. Kennedy, T., 2005. (Re)Presenting Mary Magdalene: A Feminist Reading of The Last Temptation of Christ. Journal of Religion and Popular Culture, 9.

Kennedy, T., 2012. Mary Magdalene and the Politics of Public Memory: Interrogating The Da Vinci Code. Feminist Formations, 24 (12), 120-139.

King, N., 2011. The Passion of the Christ. Houndmills, Basingstoke, Hampshire; New York: 
Palgrave Macmillan.

King of Kings, 1927. Film. Directed by Cecil B. DeMille. USA: DeMille Pictures

Corporation.

King of Kings, 1961. Film. Directed by Nicholas Ray. USA: MGM.

Knapp, L., 1999. Tsvetaeva's Marine Mary Magdalene. The Slavic and East European

Journal, 43 (4), 597-620.

Kozlovic, A., 2004. The Cinematic Christ-Figure. The Furrow, 55 (1), 26-30.

Leloup, J., 2002. The Gospel of Mary Magdalene. Rochester, Vermont: Inner Traditions.

Marks, L. U., 2000. The Skin of the Film. Durham and London. Duke University Press.

Mary, 2005. Film. Directed by Abel Ferrara. Italy, France, USA: Wild Bunch.

Mary Magdalene, 2000. TV Movie. Directed by Raffaelle Mertes, Elisabetta Marchetti. Italy, Germany: Epsilon.

Mary Magdalene, 2018. Film. Directed by Garth Davis. UK, USA, Australia: See-Saw Films. Morin, E. 2005. The Stars. Minnesota: University of Minnesota Press.

Mulvey, L., 1975. Visual Pleasure and Narrative Cinema. Screen, 16 (3), 6-18.

Negra, D., 2001. Off-White Hollywood: American Culture and Ethnic Female Stardom, London and New York: Routledge.

Olcott, S., 1912. From the Manger to the Cross. USA: Kalem Company.

Plumer, E.A., 2009. The Catholic Church and American Culture. Scranton, PA: University of Scranton Press.

Raintree County, 1957. Film. Directed by Edward Dmytryk. USA: Metro-Goldwyn-Mayer. Redmond, S., 2019. Celebrity. Oxford; New York: Routledge.

Reinhartz, A., 2007. Jesus of Hollywood. New York: Oxford University Press.

Rojek, C., 2001. Celebrity. London: Reaktion. 
Sanchez-Biosca, V., 2006. The Latin Masquerade: The Spanish in Disguise in Hollywood. In: Alastair Phillips and Ginette Vincendeau, eds. Journeys of Desire: European Actors in Hollywood. London: British Film Institute, 133-139.

Scarlet Woman: the True Story of Mary Magdalene, 2017. Film. Directed by Waldemar Januszczak. UK: XiveTV.

Superman, 1978. Film. Directed by Richard Donner. USA: Dovemead Films.

Taylor, J., 2017. What did Mary Magdalene look like? [unpublished conference paper]. Delivered at The Body Politics of Mary Magdalene conference, Warburg Institute, 24 November 2017.

The Bible, 2013. TV Miniseries. UK, USA: Lightworkers Media.

The DaVinci Code, 2006. Film. Directed by Ron Howard. USA: Columbia.

The Day the Earth Stood Still, 1951. Film. Directed by Robert Wise. USA: Twentieth Century Fox.

The Greatest Story Ever Told, 1965. Film. Directed by George Stevens. USA: MGM.

The King of Kings, 1927. Film. Directed by Cecil B. DeMille. USA: DeMille Productions. The Matrix, 1999. Film. Directed by Lana Wachowski and Lilly Wachowski (as the Wachowski Brothers). USA: Warner Bros.

The Mary Magdalene Conspiracy, 2017. Film. Directed by John Fothergill. UK: Little Dot Studios.

The Miracle Maker, 2000. Film. Directed by Derek W. Hayes and Stanislav Sokolov. Russia; $\mathrm{UK}: \mathrm{BBC}$.

The Passion of the Christ, 2004. Film. Directed by Mel Gibson. USA: Icon Productions. The Last Temptation of Christ, 1988. Film. Directed by Martin Scorsese. Canada; USA: Universal Pictures. 
The Sandpiper, 1965. Film. Directed by Vincente Minnelli. USA: Filmways Pictures.

Vertigo, 1958. Film. Directed by Alfred Hitchcock. USA: Alfred J. Hitchcock Productions.

Warren, M.J.C. and Edwards, K., 2018. Mary Magdalene - another Easter Jesus film that's

bad news for Judaism [online]. The Conversation. Available from:

https://theconversation.com/mary-magdalene-another-easter-jesus-film-thats-bad-news-forjudaism-94136 [Accessed 21 January 2019].

Warner, M., 1976. Alone of all her Sex. London: Weidenfeld and Nicholson.

Winkett, L., 2002. Go Tell! Thinking About Mary Magdalene. Feminist Theology, 29, 19-31.

\footnotetext{
${ }^{\mathrm{i}}$ Elliman, in Jesus Christ Superstar (1973); Faltskog, Scandinavium, Gothenburg, 1972; Chisholm, O2, London, 2012, following television show called Superstar on ITV to select the actor to play Jesus.


catalogue to accompany the exhibition In Search of Mary Magdalene: Images and Traditions (2002). This was on display from April 5-June 22, 2002, at The Gallery at the American Bible Society, New York.

iii It is actually July $22^{\text {nd }}$.

${ }^{\text {iv }}$ Rojek (2001) examines the convergence of celebrity culture and religion, but not in a way that develops the idea of Mary Magdalene. He does consider similarities in the way Jesus, Elvis and John Lennon are part of rituals (61). He also considers the choice of Hollywood celebrities to play the role of the Devil onscreen (73). ${ }^{\mathrm{v}}$ Casey points out that Mary Magdalene is the only person agreed upon by the gospel writers to have gone to Jesus' tomb (2010, p. 465)

vi See Casey 2010, p. 25-6 for a summary of the scholarly discreditation of Dan Brown's novel.

vii Joan Taylor presented a paper entitled 'What Did Mary Magdalene Look Like?' at The Body Politics of Mary Magdalene, a conference at the Warburg Institute in London in 2017, organized by Mary Magdalene scholar Joanne Anderson. I am hugely grateful to Professor Taylor for sharing her as yet unpublished paper with me and granting me permission to refer to it in this article.

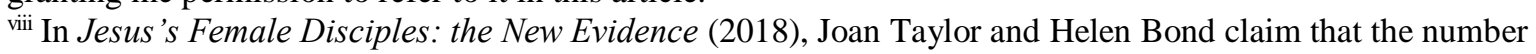
and significance of women involved in Jesus's ministry has been underestimated for centuries.

${ }^{i x}$ Vertigo replaced Citizen Kane in Sight and Sound's 2012 poll of The 50 Greatest Films of All Time (Vol 22, Issue 9, 2012).
} 